\title{
Palmoplantar Psoriasis: a review of topical therapies
}

\author{
Linden Li, Mark Taliercio, Peter W Hashim, Grace Kimmel, Ariana C Farahani and John K Nia \\ Department of Dermatology, Icahn School of Medicine at Mount Sinai, New York, NY, USA
}

\begin{abstract}
Palmoplantar psoriasis is a chronic autoimmune disease characterized by the rise of desquamative plaques on the palms and soles. Due to the thick stratum corneum of the palmoplantar regions, the search for effective topical treatments has been significantly more difficult than other forms of psoriasis. Current topical treatments include phototherapy, methotrexate gel, laser therapy, and tazarotene ointment; most treatments outside of phototherapy, however, do not have sufficient high-level clinical evaluations to justify their efficacy. In this systematic review, we explore the literature on different topical treatment regimens for palmoplantar psoriasis.
\end{abstract}

\section{Introduction}

Psoriasis is a chronic, recurring autoimmune disease that triggers the rise of scaly, red lesions on the skin, affecting approximately $2 \%$ of the global population. One clinical subtype of psoriasis localized on the palms and soles is classified as palmoplantar psoriasis (PPP). PPP affects approximately $14 \%$ of patients diagnosed with psoriasis. Characteristic effects include the formation of scaly erythematous plaques on the palms and soles, accompanied with scaling and keratinization [1]. Resulting lesions from PPP lead to functional impairments in daily activities that cause social and psychological distress. Compared to other forms of psoriasis, the disease's occurrence on the palms and soles causes a significantly greater decrease on patient's quality of life [2]. Interleukin 17 (IL-17) plays a significant role in the pathogenesis of this variant of psoriasis compared with other forms of psoriasis. Patients with PPP treated with systemic biologics targeting IL-17 tend to have favorable results [3]. Studies have attributed PPP to stem from physical activity involved in occupation. External factors correlated with manual labor, stemming from interactions with friction and mechanical stimuli, cause psoriatic lesions to become localized in pressure bearing areas $[1,4]$.

The Palmoplantar Psoriasis Area and Severity Index (PPPASI), is a point based system quantifying the area and quality of PPP. The PPPASI measures erythema, induration, and desquamation on a scale of $0-4,4$ being the most severe. The PPPASI score is widely used as a measure of improvement in many clinical studies. Some studies, however, will not refer to the PPPASI, but will measure similar symptoms using a pointbased scoring system.

Due to the thick, hyperkeratotic lesions found in palmoplantar involvement, development of effective treatments has presented a challenge [5]. Convenient application, tolerance, and low risk of adverse effects have made potent topical steroids the preferred method of treatment. Topical corticosteroids have shown variable efficacy in addressing more severe cases of psoriasis. The recalcitrant nature of the disease has rendered many topical treatments as ineffective, with symptoms recurring even after complete remission of lesions. Ultra-potent steroids under occlusion have been shown to expedite penetration and consequently bolster efficacy, but are still only administered in cases of moderate severity [6,7].
Phototherapy comes as a possible alternative with treatments such as narrow band ultraviolet-B (nb-UVB), psoralen ultraviolet A (PUVA), and excimer laser therapy. Despite the many recorded clinical successes, the long treatment period and risk of UV exposure associated with phototherapy has not made it a preferable treatment. It has been used as monotherapy and with adjunctive systemic treatments, such as acitretin, to reduce adverse effects [8]. Topical methotrexate gels and coal tar therapy, previously utilized for other subtypes of psoriasis, have had promising results [6]. Topical treatments, moreover, have shown synergic effects when used in combination with other therapies. Tazarotene cream and corticosteroids, for example, show better efficacy when combined with the application of emollients [9].

In addition to topical treatments, systemic treatments both biologic and non-biologic have been shown to be efficacious, with some biologic therapies clearing most patients. However, adverse effects, patient preferences, and financial barriers associated with systemic treatments often deter their usage. There is a paucity of adequate clinical evaluation of efficacy of topical therapies and, as a result, lack of medical consensus on the optimal treatments. Topical treatments for PPP are effective and have a low risk for adverse effects. This article seeks to evaluate the literature pertaining to topical remedies for PPP, specifically, examining the side effects and potency of each treatment option. Current and future topical prospects show potential in ameliorating the effects of the recalcitrant disease.

\section{Methods}

The authors performed a search on the National Library of Medicine's PubMed Database (up until July 30, 2016) to review the existing literature relevant to topical treatments for PPP. Keywords used that were found in the title, abstract, and body were as follows: "palmoplantar psoriasis", "topical", "steroids", "treatment". References found in articles were examined if deemed relevant to topical therapy,

Correspondence to: John K Nia, Department of Dermatology, Icahn School of Medicine at Mount Sinai Medical Center, 5 E. 98th Street, New York, NY 10029, USA, Tel: 212-241-3288; Fax: 212-876-8961; E-mail: John.Nia@mssm.edu

Received: September 15, 2016; Accepted: October 13, 2016; Published: October 17,2016 
and were used to find other sources.

\section{Results}

\section{PUVA}

Phototherapy comes as a viable, effective treatment for psoriasis due to its low risk of adverse effects and noted efficacy (Table 2). PUVA makes use of psoralen to bolster the efficacy of UVA in the treatment of psoriasis, with the most common delivery being the application of a topical 8-methoxypsoralen (8-MOP) solution. Lozinski et al. examined 248 patient in a retrospective non-randomized cohort study. In this study, paint application of a $0.1 \%$ 8-MOP gel was administered before UVA irradiation. Forty-two percent of all patients achieved complete remission of lesions with an $89 \%$ success rate. PUVA therapy, however, had to be administered over a long treatment period, with an average treatment time of 21.9 months before marked improvements were reported [10].

Hawk et al. conducted a retrospective comparative review on palmoplantar dermatoses where seven psoriasis patients achieved complete remission through PUVA with an 8-MOP gel over eighteen months [11].

In another retrospective study of forty-eight patients conducted in Spain by Carrascosa et al., an oil-in-water emulsion of a $0.1 \%$ 8-MOP gel was administered before treatment. After a treatment period of ten weeks, $62 \%$ of patients reported a satisfactory improvement in their condition [12].

In addition to the popular application of an 8-MOP gel, other alternatives have arisen and shown efficacy in phototherapy. A study involving 28 patients conducted by Abel et al. combined the topical application of a $0.1 \%$ methoxsalen solution with PUVA therapy. Sixtyfour percent of all patients $(\mathrm{N}=18)$ with PPP reported considerable improvement, with two patients achieving complete remission [13]. A different study by Neumann et al. used the application of a topical meladinine solution before phototherapy. The treatment was also effective in treating PPP, with patients' mean PPPASI scores reporting a $64.64 \%$ improvement after therapy [14].

Topical PUVA is not the only viable psoralen delivery option available to bolster phototherapeutic efficiency. Coleman et al. provided a clinical evaluation of "soak-PUVA" and metal halide lamps in reducing palmoplantar lesions. Instead of applying a gel to target areas, the affected palmoplantar areas were soaked in a bath containing an 8-MOP solution before phototherapy was administered. In a mean treatment period of twenty-eight sessions, seven patients showed more than a 50\% improvement in their initial clinical scores (erythema, scaling, thickness, and fissuring), while one reported complete resolution [15]. A randomized, single-blinded prospective study done by Schiener et al. provided a comparison between topical PUVA and soak PUVA. In the former, psoralen was administered through the application of an 8-MOP gel; in the latter, psoralen was administered through an ethanolic 8-MOP solution bath. After treatment was finished, both regimens achieved similar improvements in the Mean Severity Index (MSI) for palmoplantar dermatoses. Though PUVA-gel was able to result in a larger decrease because of a larger baseline value, its greater efficacy-compared to PUVA-bath-was not statistically significant [16].

In one study conducted in India, Khandupar et al. examined the

Table 1. Other topical

\begin{tabular}{|c|c|c|c|c|c|c|c|c|}
\hline Study & Study Design & $\mathbf{N}$ & Mean age (range) & Sex: F, M & Treatment & $\begin{array}{l}\text { Treatment } \\
\text { Period }\end{array}$ & Results & Adverse effects \\
\hline Umezewa et al. & $\begin{array}{l}\text { Randomized, } \\
\text { double-blind, } \\
\text { placebo-controlled } \\
\text { trial }\end{array}$ & 188 & $(20-79)$ & $\begin{array}{l}70,24 \text { OCT } \\
66,27 \text { placebo }\end{array}$ & $\begin{array}{l}\text { Maxacalcitol ointment } \\
\text { or placebo, twice daily } \\
\text { to all lesions }\end{array}$ & 8 weeks & $\begin{array}{l}17 \% \text { of patients reported } \\
\text { marked improvements, } \\
\text { compared to only } 2.2 \% \text { of } \\
\text { the placebo. }\end{array}$ & $\begin{array}{l}43.2 \% \text { reported adverse effects, } \\
\text { ranging from mild to moderate } \\
\text { symptoms }\end{array}$ \\
\hline Cassano et al. & $\begin{array}{l}\text { Pilot randomized } \\
\text { open label study }\end{array}$ & 40 & $\begin{array}{l}\text { Mono: } 52.3 \mathrm{yrs} \\
\text { Combo: } 48.5 \mathrm{yrs}\end{array}$ & $\begin{array}{l}\text { Mono: } 8,12 \\
\text { Combo: } 9,11\end{array}$ & $\begin{array}{l}\text { Mometasone furoate } \\
\text { ointment or co-therapy } \\
\text { with emollient cream }\end{array}$ & 4 weeks & $\begin{array}{l}\text { Area affected was } 16 \% \\
\text { for mometasone, and } 13 \% \\
\text { with emollients }(\mathrm{P}<0.01)\end{array}$ & $\begin{array}{l}\text { Corticotherapy: transient burning, } \\
\text { plantar fission, skin dryness } \\
\text { Emollients: None }\end{array}$ \\
\hline Amladi et al. & $\begin{array}{l}\text { Observer-blinded } \\
\text { randomized } \\
\text { controlled study }\end{array}$ & 30 & $\begin{array}{l}\text { Tazarotene: } 35.82 \\
\text { yrs } \\
\text { Clobetasol: } 40.38 \\
\text { yrs }\end{array}$ & - & $\begin{array}{l}\text { Topical tazarotene } \\
\text { cream }(0.1 \%) \text { or } \\
\text { clobetasol propionate } \\
\text { cream }(0.05 \%) \text { with } \\
\text { a daily application of } \\
\text { white soft paraffin }\end{array}$ & 12 weeks & $\begin{array}{l}\text { Tazarotene: ESFI score } \\
\text { from } 6.65 \text { to } 1.12 .52 .9 \% \\
\text { had complete resolution. } \\
\text { Clobetasol: ESFI score } \\
\text { from } 5.69 \text { to } 0.62 .61 .5 \% \\
\text { had complete resolution. }\end{array}$ & $\begin{array}{l}\text { Tazarotene: Itching/ } \\
\text { irritation( } 35.3 \%) \text { at the end of } \\
\text { four weeks, but resolved with } \\
\text { continued use } \\
\text { Clobetasol: Hypopigmentation } \\
(53.8 \%)\end{array}$ \\
\hline Khandpur et al. & $\begin{array}{l}\text { Randomized } \\
\text { comparative study }\end{array}$ & 52 & 31.4 yrs $(10-70)$ & 24,28 & $\begin{array}{l}\text { Clobetasol propionate } \\
0.05 \% \text { cream, and coal } \\
\text { tar ointment or topical } \\
\text { PUVAsol on alternate } \\
\text { days }\end{array}$ & 16 weeks & $\begin{array}{l}\text { Clobetasol + coal tar: PASI } \\
\text { from } 5.5 \text { to } 1.7 \text { for the } \\
\text { palms, and from } 10 \text { to } 1.6 \\
\text { for soles. } \\
\text { PUVAsol: PASI went from } \\
6.25 \text { to } 1.5 \text { for the palms, } \\
\text { and from } 8.54 \text { to } 2.7 \text { for } \\
\text { soles. }\end{array}$ & $\begin{array}{l}\text { Clobetasol + coal tar: none } \\
\text { PUVAsol: Itching, pain, erythema, } \\
\text { desquamation }(22 \%)\end{array}$ \\
\hline Adisen et al. & $\begin{array}{l}\text { Retrospective } \\
\text { analysis }\end{array}$ & 114 & $\begin{array}{l}\text { PP: } 43.5(10-72) \\
\text { PPP: } 40.2(17-68)\end{array}$ & $\begin{array}{l}\text { PP: } 31,31 \\
\text { PPP: } 33,19\end{array}$ & $\begin{array}{l}\text { Corticosteroids } 2 \text { times/ } \\
\text { day. Combination } \\
\text { therapies with other } \\
\text { topicals if still no } \\
\text { improvement. }\end{array}$ & $\geq 12$ weeks & $\begin{array}{l}27 \% \text { had marked } \\
\text { improvements with only } \\
\text { topicals. }\end{array}$ & None with topicals \\
\hline Kumar et al. & $\begin{array}{l}\text { Comparative } \\
\text { controlled study }\end{array}$ & $\begin{array}{l}\text { A: } 17 \\
\text { B: } 11\end{array}$ & $\begin{array}{l}\text { Group A: } 34.5 \\
(14-54) \\
\text { Group B: } 28.3 \\
(8-60)\end{array}$ & $\begin{array}{l}\text { A: } 10,7 \\
\text { B: } 6,5\end{array}$ & \begin{tabular}{|l|} 
Group A: $6 \%$ crude \\
coal tar ointment \\
Group B: Salicylic acid \\
in white petrolatum
\end{tabular} & 8 weeks & $\begin{array}{l}\text { A: ESI scores from } 5.5 \text { to } \\
2.2 .76 .5 \% \text { showed good } \\
\text { improvement. } \\
\text { B: ESI scores from a } 5.2 \text { to } \\
2.4 .45 .5 \% \text { showed good } \\
\text { improvement. }\end{array}$ & None for both groups \\
\hline
\end{tabular}

ESIF: erythema, scaling, induration, fissuring (based on PPASI scale) 
Table 2. PUVA.

\begin{tabular}{|c|c|c|c|c|c|c|c|c|}
\hline Study & Study Design & $\mathbf{N}$ & Mean age (range) & Sex: F, M & Treatment & $\begin{array}{l}\text { Treatment } \\
\text { Period }\end{array}$ & Results & Adverse effects \\
\hline $\begin{array}{l}\text { Carrascosa } \\
\text { et al. }\end{array}$ & $\begin{array}{l}\text { Retrospective } \\
\text { chart review }\end{array}$ & 48 & 51 yrs $(20-84)$ & 33,15 & $\begin{array}{l}\text { PUVA with 8-MOP } \\
\text { gel applied, intial } \\
\text { dose } 0.5 \mathrm{~J} / \mathrm{cm}^{2}\end{array}$ & $8-10$ weeks & $\begin{array}{l}25 \text { patients }(62 \%) \text { had } \\
\text { satisfactory response }\end{array}$ & Mild erythema in $25 \%$ \\
\hline Lozinski et al. & $\begin{array}{l}\text { Retrospective, } \\
\text { non-randomized } \\
\text { cohort study }\end{array}$ & 248 & $\begin{array}{l}\text { BB-UVB: } 40.9 \text { yrs. } \\
\text { P-PUVA: } 48 \text { yrs }\end{array}$ & 105,143 & $\begin{array}{l}\text { PUVA at initial dose } \\
0.5 \mathrm{~J} / \mathrm{cm}^{2} \text { with } 0.1 \% \\
8 \text {-MOP solution }\end{array}$ & As needed & $\begin{array}{l}42 \% \text { had complete resolution } \\
\text { with success rates } 89 \% \text {. }\end{array}$ & $\begin{array}{l}\text { Mild erythema and } \\
\text { burning }(21 \%)\end{array}$ \\
\hline $\begin{array}{l}\text { Khandpur } \\
\text { et al. }\end{array}$ & $\begin{array}{l}\text { Randomized } \\
\text { comparative study }\end{array}$ & 52 & 31.4 yrs $(10-70)$ & 24,28 & $\begin{array}{l}\text { Topical PUVAsol } \\
\text { with } 8 \text {-MOP } 1 \% \\
\text { lotion } 1 \text { days }\end{array}$ & 16 weeks & $\begin{array}{l}\text { PASI from } 6.25 \text { to } 1.5 \text { for palms, } \\
8.54 \text { to } 2.7 \text { for soles. }\end{array}$ & $\begin{array}{l}\text { PUVAsol: Itching, pain, } \\
\text { erythema, desquamation } \\
(22 \%)\end{array}$ \\
\hline $\begin{array}{l}\text { Neumann } \\
\text { et al. }\end{array}$ & $\begin{array}{l}\text { Randomized, } \\
\text { controlled trial }\end{array}$ & 10 & $47.3(11-71)$ & 4,6 & $\begin{array}{l}\text { Polychromatic UVA } \\
\text { irradiation with } \\
\text { meladinine } 0.03 \% \\
\text { solution, }\end{array}$ & As needed & $\begin{array}{l}\text { Mean PASI scores reduced from } \\
26.3 \text { to } 9.3 \text {, constituting a } 64.64 \% \\
\text { improvement. }\end{array}$ & $\begin{array}{l}\text { PUVA: Erythema and } \\
\text { mild irritation }\end{array}$ \\
\hline Abel et al. & Controlled study & 28 & $14-70$ years & 13,15 & $\begin{array}{l}\text { PUVA with } 0.1 \% \\
\text { methoxsalen at initial } \\
\text { max dose } 0.8 \mathrm{~J} / \mathrm{cm}^{2}\end{array}$ & As needed & $\begin{array}{l}64 \% \text { experienced near complete } \\
\text { clearing, } 2 \text { patients achieved } \\
\text { complete remission. }\end{array}$ & $\begin{array}{l}\text { Localized pigmentation, } \\
\text { pruritus }(42.9 \%) \text {, } \\
\text { erythema }(28.6 \%) \text {, } \\
\text { blistering }(28.6 \%) \text {, }\end{array}$ \\
\hline Coleman et al. & $\begin{array}{l}\text { Retrospective, } \\
\text { uncontrolled study }\end{array}$ & 11 & $32-69$ years & 6,5 & $\begin{array}{l}\text { 8-MOP solution to } \\
\text { soak hands and feet, } \\
\text { then UVA from metal } \\
\text { halide lamp and } \\
\text { portable emitter at } \\
\text { initial dose } 0.25 \mathrm{~J} / \mathrm{cm}^{2}\end{array}$ & As needed & $\begin{array}{l}7 \text { patients achieved }>50 \% \text { of } \\
\text { clearing, while } 1 \text { achieved } \\
\text { complete resolution. }\end{array}$ & $\begin{array}{l}\text { Erythema }(45 \%) \text {, pruritus } \\
(9 \%) \text {, vesiculation }(9 \%)\end{array}$ \\
\hline Schiener et al. & $\begin{array}{l}\text { Randomized, } \\
\text { single-blinded } \\
\text { prospective }\end{array}$ & 8 & 51 yrs (24-75) & 12,8 & $\begin{array}{l}\text { UVA at initial max } \\
\text { dose } 0.5 \mathrm{~J} / \mathrm{cm}^{2} \text { with } \\
\text { either } 8 \text {-MOP gel } \\
\text { or } 0.3 \% \text { ethanolic } \\
8 \text {-MOP-solution } \\
\text { dissolved in warm } \\
\text { water }\end{array}$ & As needed. & $\begin{array}{l}\text { Mean ASI scores decreased from } \\
26.6 \text { to } 3 \text { for PUVA bath and from } \\
27.25 \text { to } 2.5 \text { for PUVA gel after } \\
\text { treatment. }\end{array}$ & - \\
\hline Hawk et al. & $\begin{array}{l}\text { Retrospective } \\
\text { comparative } \\
\text { review }\end{array}$ & 14 & $50.8(13-84)$ & 15,10 & $\begin{array}{l}\text { 8-MOP emulsion } \\
\text { with UVA at initial } \\
\text { dose } 0.25 \mathrm{~J} / \mathrm{cm}^{2}\end{array}$ & 18 months & $\begin{array}{l}7 \text { achieved complete remission, } \\
\text { while } 3 \text { reported an improvement. }\end{array}$ & $\begin{array}{l}\text { Transient irritation of } \\
\text { exposed area }\end{array}$ \\
\hline Layton et al. & $\begin{array}{l}\text { Double-blind, } \\
\text { placebo-controlled } \\
\text { trial }\end{array}$ & 27 & - & - & $\begin{array}{l}\text { 8-MOP in hydrophilic } \\
\text { water/oil emulsion } \\
\text { with PUVA at initial } \\
\text { dose } 1 \mathrm{~J} / \mathrm{cm}^{2}\end{array}$ & 8 weeks & $\begin{array}{l}\text { Both the placebo and topical } \\
\text { PUVA improved compared to the } \\
\text { baseline at week } 8(\mathrm{p}<0.004)\end{array}$ & $\begin{array}{l}\text { Blistering, pruritus, } \\
\text { erythema }\end{array}$ \\
\hline
\end{tabular}

ASi: Area Severity Index; PASI: Psoriasis ASI

Table 3. UVB treatments.

\begin{tabular}{|c|c|c|c|c|c|c|c|c|}
\hline Study & Study Design & $\mathbf{N}$ & Mean age (range) & Sex: F, M & Treatment & Treatment Period & Results & Adverse effects \\
\hline Gupta et al. & Therapeutic evaluation & 12 & - & - & $\begin{array}{l}\text { NB-UVB with } \\
\text { initial dose } 280 \mathrm{~J} / \\
\mathrm{cm}^{2} \text { given every } \\
\text { other day }\end{array}$ & 8 weeks & $\begin{array}{l}91.66 \% \text { of all patients had } \\
51-75 \% \text { improvements } \\
\text { in their ESIF scores, but } \\
33.33 \% \text { reported recurrence }\end{array}$ & $\begin{array}{l}\text { Erythema and stinging } \\
\text { pain on exposed body } \\
\text { part }(16.67 \%) ;\end{array}$ \\
\hline Lozinski et al. & $\begin{array}{l}\text { Retrospective, non- } \\
\text { randomized cohort study }\end{array}$ & 248 & $\begin{array}{l}\text { BB-UVB: } 40.9 \text { yrs } \\
\text { P-PUVA: } 48 \text { yrs }\end{array}$ & 105,143 & $\begin{array}{l}\text { Waldman's UVB } \\
\text { unit at initial dose } \\
0.15 \mathrm{~mJ} / \mathrm{cm}^{2}\end{array}$ & As needed & $\begin{array}{l}30 \% \text { of all patients had } \\
\text { complete resolution with a } \\
54 \% \text { success rate. }\end{array}$ & $\begin{array}{l}\text { Mild erythema and } \\
\text { burning }(11 \%)\end{array}$ \\
\hline
\end{tabular}

PASi: Psoriasis Area Severity Index

therapeutic combination of solar UVA radiation and 8-MOP solutions. Fifty-two patients patients applied topical 1\% 8-MOP lotion and were exposed to natural sunlight as a replacement for regular PUVA. Mean PASI scores went from 6.25 to 1.5 in the palms, and from 8.54 to 2.7 in the soles, proving the effectiveness of solar radiation as an alternative treatment [7].

Phototherapy is preferred over systemic treatments for its low risk of adverse effects and sustainable efficacy. Mild erythema, burning, and irritation was reported in all studies, but did not affect patients to the extent where treatment was stopped $[10,12,14]$.

\section{NB-UVB and BB-UVB}

Ultraviolet-B frequencies have also been clinically evaluated as a treatment option for PPP (Table 3). In a study involving twelve patients done by Gupta et al., nb-UVB monotherapy resulted in a 51-
75\% improvement in baseline ESIF scores in $91.66 \%(\mathrm{~N}=11)$ of all PPP patients [17]. A retrospective non-randomized cohort study done by Lozinski et al. involving 248 patients evaluated the efficacy of both paint-PUVA and BB-UVB as treatments to PPP. After an average of 16.75 months, $30 \%$ of PUVA patients achieved complete resolution while $24 \%$ reported a partial response ( $>50 \%$ improvement according to the evaluating dermatologist). The report showed that paint PUVA was superior in its efficacy and success rate $(p<0.001)$. Patients on the p-PUVA treatment also reported longer periods of remission than those on BB-UVB, with times of $21.9 \pm 1.34$ months versus $16.75 \pm$ 1.83 months, respectively $(p<0.01)[10]$.

Adverse effects after UVB treatment were similar to those associated with PUVA: patients reported erythema and burning on exposed target areas $[10,17]$. 


\section{Excimer light therapy and laser treatments}

Despite the limited clinical evaluation of excimer light as a viable phototherapy option in the treatment of PPP, some studies have deemed it an efficacious alternative to the PUVA and UVB treatments. Excimer light therapy requires a less accumulative dose to ameliorate symptoms, and so, treats PPP in a time-efficient manner (Table 4). Fewer treatments reduce the total time exposed to light, leading to a lower risk for adverse effects related to phototoxicity $[1,18]$.

Furuhashi et al. examined the efficacy of a $380 \mathrm{~nm}$ excimer light in treating PPP on twenty patients. After 30 weeks of treatment, PPPASI scores decreased from a baseline of 19.5 to 9.5 [19]. A further study involving ten patients with mild to severe PPP, led by Goldberg et al., reinforced previous clinical evaluations of excimer light therapy. After receiving a mean of eleven treatments, all patients showed improvements from their baseline PASI score with 50-100\% improvements in area and erythema [18].

A randomized controlled trial done by Neumann et al. sought to compare excimer light therapy with topical PUVA. Palmoplantar lesions were randomly treated with either irradiation from a $308 \mathrm{~nm}$ MEL or PUVA delivered via a meladinine solution. All ten patients involved in the study had mean improvements in their PASI scores, with no statistically significant difference between the two reductions ( $p$ $\leq 0.581$ ). No adverse effects were noted in two out of the three studies, with the one only reporting mild erythema on exposed target areas. Excimer laser therapy, a similar treatment regimen to PUVA with the same efficacy, stands as a future prospect for the treatment of PPP [14].

In a pilot prospective study of thirty-three patients done by Nisticò et al., the use of a UVA-1 laser saw 75\% of all patients achieve complete resolution, while 50-75\% improvements were observed in $25 \%$ based on PPPASI scores. Final scores showed statistically significant improvements when compared to those of the baseline $(p<0.05)$. Maintenance treatments were administered after phototherapy at a fixed dose of $80 \mathrm{~J} / \mathrm{cm}^{2}$, allowing $82 \%$ of all patients to maintain their remission of symptoms [20].

Kim et al. reported a case of one patient with PPP received a 632 $\mathrm{nm}$ diode laser treatment. After the patient applied a $20 \%$ topical 5-aminolaevulinic acid, the patient achieved complete remission and sustained these results through maintenance treatments. The level of evidence is weak in this study; however, because of the noted success that the patient experienced, further clinical evaluation is needed to verify the efficacy of the reported laser therapy [21].

\section{Topical methotrexate gel}

Systemic methotrexate is commonly used treating psoriasis (Table 5). Despite its efficacy, systemic methotrexate has well known side effects including hepatitis and gastrointestinal discomfort [22]. Topical methotrexate has been used as an auspicious alternative with less adverse effects. Lack of rigorous clinical evaluation, however, has prevented it from being embraced as a treatment for PPP. In a prospective, open label study involving fourteen patients done by Kumar et al., patients were treated with topical methotrexate $0.25 \%$ gel in a hydroxgel base. Results varied between the palms and the soles: three patients experienced moderate improvement, while nine reported insignificant improvements in their palmar lesions. No improvement was noted in plantar lesions, six patients noting mild improvements, and three patients with minimal improvements. The improvements were insignificant when compared to other PPP treatments. Lack of adequate response in patients was attributed to an insufficient concentration ( $0.25 \%)$, and a lack of penetration with the thick epidermal layer of the palmoplantar regions [23].

Ravi et al. provided a similar prospective evaluation on topical methotrexate gel. Unlike the previous study, however, a higher concentration of topical $1 \%$ methotrexate gel was administered. Patients applied the ointment twice daily during a treatment period of eight weeks. $30 \%$ of patients with palmer lesions had a $>75 \%$ improvement in their ESIF score, 50\% reported marked improvement, and $20 \%$ reported moderate improvement. $21.4 \%$ of patients with plantar lesions reported near total clearing, $42.8 \%$ had marked improvement, and $28.3 \%$ had moderate improvement. With topical methotrexate administered at two different levels, results show that a greater concentration yields more significant improvements. The topical methotrexate gel was well tolerated in both studies and no adverse effects were reported [24].

\section{Other topical ointments and corticosteroids}

Derivations of tar from coal can be used in the treatment of PPP have been studied due to their capacity in ameliorating symptoms without posing a large risk of adverse reactions (Table 1). In a comparative

Table 4. Laser therapies.

\begin{tabular}{|c|c|c|c|c|c|c|c|c|}
\hline Study & Study Design & $\mathbf{N}$ & Mean age (range) & Sex: F, M & Treatment & Treatment Period & Results & Adverse effects \\
\hline Nisticò et al. & $\begin{array}{l}\text { Pilot prospective } \\
\text { study }\end{array}$ & 33 & 42.6 yrs (23-67) & 12,21 & $\begin{array}{l}\text { UVA-1 at fixed range } 80 \\
140 \mathrm{~J} / \mathrm{cm}^{2} \text {, maintenance at } \\
80 \mathrm{~J} / \mathrm{cm}^{2}\end{array}$ & $\begin{array}{l}16 \text { sessions with } 3 \\
\text { months observation }\end{array}$ & $\begin{array}{l}75 \% \text { of all patients } \\
\text { achieved complete } \\
\text { resolution. } 82 \% \text { of } \\
\text { patients maintained } \\
\text { resolution in follow-up. }\end{array}$ & $\begin{array}{l}24 \% \text { of all patients } \\
\text { experienced prolonged } \\
\text { erythema for } 24-48 \\
\text { hours. }\end{array}$ \\
\hline Furuhashi et al. & Open-label study & 20 & - & - & $\begin{array}{l}\text { Excimer at initial dose } \\
0.3 \mathrm{~J} / \mathrm{cm}^{2}\end{array}$ & 30 weeks & $\begin{array}{l}\text { PPPASI score from } \\
19.5 \text { to } 9.5 \text {. }\end{array}$ & None \\
\hline Goldberg et al. & $\begin{array}{l}\text { Prospective cohort } \\
\text { study }\end{array}$ & 10 & $18-75$ years & - & $\begin{array}{l}\text { Excimer with dosage } \\
\text { from } 400-600 \mathrm{~mJ} / \mathrm{cm}^{2}\end{array}$ & As needed & $\begin{array}{l}50-100 \% \\
\text { improvements in } \\
\text { plaques and erythema } \\
\text { according to PASI }\end{array}$ & None \\
\hline Neumann et al. & $\begin{array}{l}\text { Randomized } \\
\text { controlled trial }\end{array}$ & 10 & $47.3(11-71)$ & 4,6 & $\begin{array}{l}\text { Excimer with power } \\
\text { density of } 48 \mathrm{~mW} / \mathrm{cm}^{2}\end{array}$ & As needed & $\begin{array}{l}\text { Mean PASI scores } \\
\text { reduced from } 28 \text { to } \\
10.2\end{array}$ & $\begin{array}{l}\text { Erythema on exposed } \\
\text { skin. }\end{array}$ \\
\hline Kim et al. & Case study & 1 & 27 & 1,0 & $\begin{array}{l}\text { Topical 5-aminolaevulinic } \\
\text { acid before irradiation } \\
\text { from } 632 \mathrm{~nm} \text { diode lazer } \\
\text { at dose } 15 \mathrm{~J} / \mathrm{cm}^{2} \text {. }\end{array}$ & 11 treatments & $\begin{array}{l}\text { Complete clearance } \\
\text { after treatment with } \\
\text { maintenance treatment } \\
\text { administered every } \\
\text { other week afterwards. }\end{array}$ & $\begin{array}{l}\text { Slight burning during } \\
\text { light exposure }\end{array}$ \\
\hline
\end{tabular}


Table 5. Topical methotrexate

\begin{tabular}{|c|c|c|c|c|c|c|c|c|}
\hline Study & Study Design & $\mathbf{N}$ & Mean age (range) & Sex: F, M & Treatment & $\begin{array}{l}\text { Treatment } \\
\text { Period }\end{array}$ & Results & Adverse effects \\
\hline Kumar et al. & $\begin{array}{l}\text { Prospective cohort } \\
\text { study }\end{array}$ & 14 & 41.5 yrs (18-57) & 3,11 & $\begin{array}{l}\text { Topical } \\
\text { methotrexate } \\
0.25 \% \text { gel in a } \\
\text { hydroxgel base }\end{array}$ & 12 weeks & $\begin{array}{l}\text { Moderate improvement in three patients, } \\
\text { mild improvement in seven patients, with } \\
\text { palmar lesions. For plantar lesions, six } \\
\text { patients had mild improvements, and three } \\
\text { had minimal improvements. }\end{array}$ & - \\
\hline Ravi et al. & $\begin{array}{l}\text { Prospective cohort } \\
\text { study }\end{array}$ & 16 & - & - & $\begin{array}{l}1 \% \text { methotrexate } \\
\text { gel applied twice } \\
\text { daily }\end{array}$ & 8 weeks & $\begin{array}{l}\text { Mean ESIF scores from } 6.9 \text { to } 2.6 \text { for } \\
\text { palms and } 7.1 \text { to } 3.1 \text { for soles. } 30 \% \text { with } \\
\text { palmer lesions had near total clearing, } \\
50 \% \text { reported marked improvement. } \\
21.4 \% \text { of patients with plantar lesions } \\
\text { reported near total clearing, } 42.8 \% \text { had } \\
\text { marked improvement. }\end{array}$ & None. \\
\hline
\end{tabular}

ESIF: erythema, scaling, induration, fissuring (based on PPPASI scale)

controlled study done by Kumar et al., the efficacy of coal tar therapy was compared with a salicylic acid control group. The coal tar ointment used in the former group contained salicylic acid in a white petrolatum gel as an ointment base. $76.5 \%$ of all seventeen patients treated with a $6 \%$ crude coal tar ointment reported $>50 \%$ improvements in their symptoms. Results found that the addition of coal tar bolstered improvement rates and time-efficiency, with only $45.5 \%$ of patients reporting $>50 \%$ improvement in the salicylic acid group [25].

Another randomized comparative study of fifty-two patients done by Khandpur et al. showed that coal tar combination therapy had a greater efficacy than solar PUVA irradiation in addressing PPP. One patient group received a coal tar ointment with a salicylic acid base in combination with clobetasol propionate gel, while the other received an 8-MOP gel combined with solar PUVA treatment. After a sixteenweek treatment period, mean PASI reductions in the steroid and coal tar combination exceeded the results of those that received solar radiation. In comparison, however, both treatments were effective in different regions: coal tar treatment showed greater resolution in plantar lesions, while phototherapy was more effective in addressing palmar lesions [7].

In addition to coal tar therapy, different ointments have been clinically evaluated as treatment options to PPP. A study of maxacalcitol ointment involving 188 patients showed that $17 \%$ of test subjects reported marked improvements compared to $2.2 \%$ in the placebo group, with differences in efficacy being statistically significant $(p<0.0001) .43 .2 \%$ of patients on the maxacalcitol ointment, however, reported a wide range of mild and moderate adverse effects [26].

Topical retinoids have emerged as a possible replacement to potent corticosteroids. An observer-blinded randomized controlled study of thirty patients done by Amladi et al. sought to provide a comparison between tazarotene and clobetasol. In the group receiving a daily application of tazarotene cream, 52.9\% of PPP patients achieved complete resolution and $41.1 \%$ reported $>50 \%$ improvements on the Physician's Global Assessment (PGA). Though the latter was able to achieve a $>50 \%$ PGA improvement in all involved patients, $53.8 \%$ of them reported hypopigmentation. Tazarotene ointment caused itching in $35.3 \%$ of all patients, but was resolved with continued therapy [9].

Topical treatments have been unsuccessful in treating some cases of PPP because the thick stratum corneum of the palms prevents adequate penetration. Occlusive films have been used as a possible therapeutic enhancement to bolster penetration, and are more effective than simply applying topical treatments [27]. A study conducted by Duweb et al. sought to provide a comparison between occlusive and non-occlusive applications of topical calcipotriol gel in treating PPP.
Results showed that in six weeks, occlusive calcipotriol applied twice weekly had the same efficacy as non-occlusive calcipotriol applied twice daily. The treatment used under occlusion at a significantly lower frequency still resulted in the same improvement in erythema, scaling, and thickness $(p<0.001)$ [28].

Topical corticosteroids and ointments are preferred over systemic treatments because of convenient application and little risk of adverse effects. In the studies evaluated it is evident that adverse effects are still relatively common in newer treatments such as maxacalcitol and tazarotene.

\section{Emollients as an adjunctive therapy}

The use of emollients in conjunction with topical therapies provides a promising synergic remedy for PPP. Application of emollients provides a film that hinders water evaporation from the skin, increasing hydration in the stratum corneum and consequently reducing scaling and erythema associated with psoriasis. Due to their therapeutic effects that improve patient comfort, emollients are recommended as an adjunct to be used in combination therapy with other treatments. Hydration in the stratum corneum resulting from the application of emollients can increase occlusion and expedite penetration by topical corticosteroids [29]. A comparative study done by Cassano et al. evaluated the adjuvant role of emollients with corticosteroids. When comparing mometasone furoate ointment-a monotherapy and the addition of emollients as a combination therapy, patients in the former experienced statistically significant improvements. At the end of the four-week treatment period, areas affected by PPP were $16 \%$ and $13 \%$ for corticotherapy and combination therapy, respectively $(p<0.01)$. Softening of the stratum corneum, especially in palmoplantar regions with a thick epidermal layer, bolsters the effectiveness of topical treatments when used as an adjunct. Emollients have also seen application with phototherapy in reducing adverse effects [23]. In a study conducted by Abel et al., pruritus commonly associated with PUVA irradiation was resolved through emollient application [13].

\section{Discussion}

Due to the negative impact of PPP on quality of life, a maintainable remedy is needed to treat the long-term disease and prevent recurrence. The authors reviewed the following therapies: PUVA, nb/bb-UVB, laser treatments, topical methotrexate, tazarotene, maxacalcitol, calcipotriol, and other topical corticosteroids.

Topical corticosteroids are an efficacious solution that should remain as the first line of treatment for PPP. When compared with the other therapeutic options, topical steroids have a smaller risk of 
adverse reactions during the treatment period. Amladi et al. [9] proved the efficacy of clobetasol propionate cream as a viable treatment option. All patients exhibited at least a good response, with some achieving complete resolution after the treatment period. Despite the adverse effects associated with clobetasol as a monotherapy, Khandpur et al. [7] proves that the use of coal tar therapy in combination can reduce the risk. In the combination therapy, patients reported greater efficacy in healing and no adverse effects. It is recommended that topical corticosteroids be used in combination with other therapies to reduce the risk of adverse reactions and bolster efficacy [29].

Other topical ointments, some previously used in the treatment of psoriasis vulgaris, have recently begun to show promise. Topical methotrexate had variable results between the two analyzed studies because of the different concentrations. Based on the study conducted by Ravi et al., a 1\% topical methotrexate gel shows effectiveness is ameliorating PPP symptoms with no safety concerns [24]. This was notably better than the Japanese study on topical maxacalcitol ointment, with a greater improvement rate and a reduced risk of adverse effects. In the one study done on tazarotene ointment, many patients reported complete resolution of symptoms and excellent responses as a result of the treatment [26].

In more severe cases of PPP, the clinical evaluation in the status quo shows that topical ointments and corticosteroids are sometimes insufficient as a treatment option. All modalities of phototherapy show significant efficacy in dealing with PPP, with prolonged exposure having already shown many cases of marked improvements and complete remissions. PUVA, and nb/bb UVB have arisen as phototherapeutic options, but the former has shown greater statistical efficacy than the latter in high-level comparative studies. The rise of laser therapy, however, could provide an efficacious alternative to phototherapy. The length of PUVA and UVB treatments results in prolonged exposure to ultraviolet radiation, increasing the risk of skin cancer. Excimer laser therapy and topical PUVA treatments show similar results in treatment, but the former's treatment period is significantly shorter. Though PUVA and UVB frequencies do report a high efficacy in treating PPP, better alternatives that reduce ultraviolet exposure should be used as a replacement. A shift in treatment, however, requires that rigorous clinical evaluation be conducted to validate the efficacy and safety of new therapies.

The implementation of correct and effective treatment regimens stands as the best way to treat PPP. Clinical evaluation and further research is needed to achieve medical consensus on the best topical therapy for PPP. A variety of possible treatment options has created promise in the development of effective remedies; future validation with high level studies is needed to properly evaluate topical therapies.

\section{References}

1. Bolognia J, Jorizzo JL, Rapini RP (2008) Dermatology. (2ndedtn). St. Louis: Mosby Elsevier.

2. Pettey AA, Balkrishnan R, Rapp SR, Fleischer AB, Feldman SR (2003) Patients with palmoplantar psoriasis have more physical disability and discomfort than patients with other forms of psoriasis: implications for clinical practice. J Am Acad Dermatol 49: 271-275.[Crossref]

3. Lee E, Zarei M, LaSenna C, Villada G, Romanelli P (2015) Psoriasis Targeted Therapy: Characterization of Interleukin 17A Expression in Subtypes of Psoriasis. J Drugs Dermatol 14: 1133-1136.[Crossref]

4. Kumar B, Saraswat A, Kaur I (2002) Palmoplantar lesions in psoriasis: a study of 3065 patients. Acta Derm Venereol 82: 192-195.[Crossref]

5. Jacobi A1, Mayer A, Augustin M (2015) Keratolytics and emollients and their role in the therapy of psoriasis: a systematic review. Dermatol Ther (Heidelb) 5: 1-18. [Crossref]

6. Adişen E, Tekin O, Gülekon A, Gürer MA (2009) A retrospective analysis of treatment responses of palmoplantar psoriasis in 114 patients. J Eur Acad Dermatol Venereol 23 : 814-819.[Crossref]

7. Khandpur S, Sharma VK (2011) Comparison of clobetasol propionate cream plus coal tar vs. topical psoralen and solar ultraviolet A therapy in palmoplantar psoriasis. Clin Exp Dermatol 36: 613-616. [Crossref]

8. Raposo I, Torres T (2016) Palmoplantar Psoriasis and PalmoplantarPustulosis: Current Treatment and Future Prospects. Am J Clin Dermatol 17: 349-358.[Crossref]

9. Mehta BH, Amladi ST (2011) Evaluation of topical $0.1 \%$ tazarotene cream in the treatment of palmoplantar psoriasis: an observer-blinded randomized controlled study. Indian J Dermatol 56: 40-43. [Crossref]

10. Lozinski A, Barzilai A, Pavlotsky F (2016) Broad-band UVB versus paint PUVA for palmoplantar psoriasis treatment. J Dermatolog Treat 27: 221-223.[Crossref]

11. Hawk JL, Grice PL (1994) The efficacy of localized PUVA therapy for chronic hand and foot dermatoses. Clin Exp Dermatol 19: 479-482.[Crossref]

12. Carrascosa JM, Plana A, Ferrándiz C (2013) Effectiveness and safety of psoralenUVA (PUVA) topical therapy in palmoplantar psoriasis: a report on 48 patients. Actas Dermosifiliogr 104: 418-425.[Crossref]

13. Abel EA, Goldberg LH, Farber EM (1980) Treatment of palmoplantar psoriasis with topical methoxsalen plus long-wave ultraviolet light. Arch Dermatol 116: 1257-1261. [Crossref]

14. Neumann NJ, Mahnke N, Korpusik D, Stege H, Ruzicka T (2006) Treatment of palmoplantar psoriasis with monochromatic excimer light $(308-\mathrm{nm})$ versus cream PUVA. Acta Derm Venereol 86:22-24. [Crossref]

15. Coleman WR, Lowe NJ, David M, Halder RM (1989)Palmoplantar psoriasis: Experience with 8-methoxypsoralen soaks plus ultraviolet A with the use of a highoutput metal halide device. J Am Acad Dermatol 20:1078-1082. [Crossref]

16. Schiener R, Gottlöber P, Müller B, Williams S, Pillekamp H, et al. (2005) PUVA-gel vs. PUVA-bath therapy for severe recalcitrant palmoplantardermatoses. Photodermatol Photoimmunol Photomed 21:62-67. [Crossref]

17. Gupta S, Singh K, Lalit M (2011) Comparative therapeutic evaluation of different topicals and narrow band ultraviolet B therapy combined with systemic methotrexate in the treatment of palmoplantar psoriasis. Indian J Dermatol 56:165-170. [Crossref]

18. Goldberg DJ, Chwalek J, Hussain M (2011) 308-nm Excimer laser treatment of palmoplantar psoriasis. J Cosmet Laser Ther 13: 47-49.[Crossref]

19. Furuhashi T, Torii K, Kato H, Nishida E, Saito C, et al. (2011) Efficacy of excimer light therapy $(308 \mathrm{~nm})$ for palmoplantarpustulosis with the induction of circulating regulatory T cells. Exp Dermatol 20:768-770. [Crossref]

20. Nisticò SP, Saraceno R, Chiricozzi A, Giunta A, Di Stefani A, et al. (2013) UVA-1 laser in the treatment of palmoplantarpustular psoriasis. Photomed Laser Surg 31: 434-438. [Crossref]

21. Kim YC, Lee ES, Chung PS, Rhee CK (2005) Recalcitrant palmoplantarpustula psoriasis successfully treated with topical 5-aminolaevulinic acid photodynamic therapy. Clin Exp Dermatol 30:723-724.

22. Yamamoto T (2009) Extra-palmoplantar lesions associated with palmoplantarpustulosis J EurAcad Dermatol Venereol 23: 1227-1232.[Crossref]

23. Kumar B, Sandhu K, Kaur I (2004) Topical $0.25 \%$ methotrexate gel in a hydrogel base for palmoplantar psoriasis. J Dermatol 31: 798-801.[Crossref]

24. Ravi Kumar BC, Kaur I, Kumar B (1999) Topical methotrexate therapy in palmoplantar psoriasis. Indian J Dermatol Venereol Leprol 65: 270-272.[Crossref]

25. Kumar U, Kaur I, Dogra S, De D, Kumar B (2010) Topical tazarotene vs. coal tar in stable plaque psoriasis. Clin Exp Dermatol 35: 482-486.[Crossref]

26. Umezawa Y, Nakagawa H, Tamaki K (2016) Phase III clinical study of maxacalcito ointment in patients with palmoplantarpustulosis: A randomized, double-blind, placebo-controlled trial. J Dermatol 43:288-293. [Crossref]

27. Raposo I, Torres T (2016) Palmoplantar Psoriasis and PalmoplantarPustulosis: Curren Treatment and Future Prospects. Am J Clin Dermatol 17:349-358. [Crossref]

28. Duweb GA, Abuzariba O, Rahim M, al-Taweel M, al-Alem S, et al. (2001) Occlusive 
versus nonocclusivecalcipotriol ointment treatment for palmoplantar psoriasis. Int $J$ Tissue React 23:59-62. [Crossref]
29. Fluhr JW, Cavallotti C, Berardesca E (2008) Emollients, moisturizers, and keratolytic agents in psoriasis. Clin Dermatol 26: 380-386.[Crossref]

Copyright: $\odot 2016 \mathrm{Li} \mathrm{L}$. This is an open-access article distributed under the terms of the Creative Commons Attribution License, which permits unrestricted use, distribution, and reproduction in any medium, provided the original author and source are credited. 